\title{
Kataphysical inquiry, onto-relationality and elemental forms in T.F. Torrance's doctrine of the mediation of Jesus Christ
}

\begin{tabular}{|c|c|}
\hline \multicolumn{2}{|c|}{$\begin{array}{l}\text { Author: } \\
\text { Martin M. Davis }{ }^{1,2}\end{array}$} \\
\hline \multicolumn{2}{|c|}{$\begin{array}{l}\text { Affiliations: } \\
{ }^{1} \text { Faculty of Theology, } \\
\text { North-West University, } \\
\text { Potchefstroom Campus, } \\
\text { South Africa }\end{array}$} \\
\hline \multicolumn{2}{|c|}{$\begin{array}{l}{ }^{2} \text { Greenwhich School of } \\
\text { Theology, All Nations } \\
\text { Christian Church } \\
\text { International }\end{array}$} \\
\hline \multicolumn{2}{|c|}{$\begin{array}{l}\text { Correspondence to: } \\
\text { Martin Davis }\end{array}$} \\
\hline \multicolumn{2}{|c|}{$\begin{array}{l}\text { Email: } \\
\text { revmartindavis@gmail.com }\end{array}$} \\
\hline \multicolumn{2}{|c|}{$\begin{array}{l}\text { Postal address: } \\
125 \text { Sandstone Drive, } \\
\text { Brandon, MS 39047, USA }\end{array}$} \\
\hline \multicolumn{2}{|c|}{$\begin{array}{l}\text { Received: } 12 \text { Jan. } 2012 \\
\text { Accepted: } 22 \text { May } 2012 \\
\text { Published: } 07 \text { June } 2013\end{array}$} \\
\hline \multicolumn{2}{|c|}{$\begin{array}{l}\text { How to cite this article: } \\
\text { Davis, M.M., 2013, } \\
\text { 'Kataphysical inquiry, onto- } \\
\text { relationality, and elemental } \\
\text { forms in T.F. Torrance's } \\
\text { doctrine of the mediation of } \\
\text { Jesus Christ', In die Skriflig/ } \\
\text { In Luce Verbi 47(1), Art. \#100, } \\
9 \text { pages, http://dx.doi.org/ } \\
10.4102 / \text { ids.v47i1.100 }\end{array}$} \\
\hline \multicolumn{2}{|c|}{$\begin{array}{l}\text { Copyright: } \\
\text { (C) 2013. The Authors. } \\
\text { Licensee: AOSIS } \\
\text { OpenJournals. This work } \\
\text { is licensed under the } \\
\text { Creative Commons } \\
\text { Attribution License. }\end{array}$} \\
\hline \multicolumn{2}{|l|}{ Read online: } \\
\hline 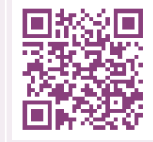 & $\begin{array}{l}\text { Scan this QR } \\
\text { code with your } \\
\text { smart phone or } \\
\text { mobile device } \\
\text { to read online. }\end{array}$ \\
\hline
\end{tabular}

The doctrine of the mediation of Jesus Christ in the scientific theology of T.F. Torrance rests on the fundamental methodological axiom that knowledge is developed according to the nature (kata physin) of the object of scientific inquiry. To know God through the incarnate Son, who is 'of one nature with the Father', is to know God in strict accordance with God's nature and hence in a theologically scientific way. In Torrance's kataphysical method, a priori knowledge of God is excluded, for epistemology follows ontology. Because the fundamental aspects of reality are relational rather than atomistic, a scientific theological approach to the doctrine of the mediation of Jesus Christ requires that he be investigated within the nexuses of 'beingconstituting' interrelations, or 'onto-relations', which disclose his identity as incarnate Saviour of the world. Following the principle of logical simplicity, the vast and scattered array of Torrance's thought can be reduced to a minimal number of elemental forms that succinctly describe in a unitary, non-dualist manner the onto-relations that constitute the identity of the incarnate Son. The primary elemental forms of Torrance's doctrine of mediation are the Nicene homoousion and the Chalcedonian doctrine of the hypostatic union. Two additional elemental forms that readily arise as corollaries of the doctrine of the hypostatic union are the doctrines of incarnational redemption and the 'vicarious humanity' of Jesus Christ. These elemental forms provide a conceptual lens for a theologically holistic view of the mediation of Jesus Christ in the scientific theology of T.F. Torrance.

Die leer van die versoening van Christus in die wetenskaplike teologie van T.F. Torrance berus op die fundamentele metodologiese aanname dat kennis volgens die aard (kataphysin) van die voorwerp van wetenskaplike ondersoek verwerf word. Om God deur die vleesgeworde Seun (wat een in wese met die Vader is) te ken, is om Hom in noue ooreenstemming met sy wese en daarom op 'n teologies-wetenskaplike wyse te ken. Volgens Torrance se katafisiese metode is aprioriese kennis van God nie moontlik nie, omdat die ontologie aan die epistemologie voorafgaan. Aangesien die fundamentele kenmerke van die werklikheid relasioneel eerder as atomisties is, vereis ' $n$ wetenskaplik-teologiese benadering tot die leer van die versoening van Christus dat die ondersoek binne die kader van 'wesensbepalende' verhoudings of 'onto-verhoudings' plaasvind. Dit is immers laasgenoemde wat Christus se identiteit as vleesgeworde Verlosser van die wêreld blootlê. Deur die beginsel van logiese eenvoud toe te pas, kan die omvangryke en sporadiese idees van Torrance gereduseer word tot 'n kleiner aantal kernelemente wat op 'n unitêre, ondubbelsinnige wyse die 'onto-verhoudings' wat die identiteit van die vleesgeworde Seun verteenwoordig, duidelik beskryf. Die vernaamste kernelemente van Torrance se leer oor die middelaarskap is die Niceaanse homoousion en die Chalcedoniese leer van die wesenseenheid. Twee opvallende, parallelle kernelemente by die leer van die wesenseenheid is die leer van die verlossing op grond van die vleeswording en die plaasvervangende mensheid van Jesus Christus. Hierdie kernelemente verskaf 'n konsepsuele lens waardeur 'n teologiese, holistiese beskouing van die middelaarskap van Jesus Christus in die wetenskaplike teologie van T.F. Torrance ondersoek kan word.

\section{Introduction}

Thomas F. Torrance (1913-2007) is widely regarded as the most important British academic theologian of the twentieth century. As one of the leading theologians in the dialogue between theology and the philosophy of science, he is especially noted for his contribution to the study of the relationship between Christian theology and the natural sciences (Neidhardt 1989:87ff.; McGrath 1999:xi; Colyer 2001a:15; Grenz 2004:201).

The 'core engagement' in Torrance's theological science is the independent reality of God and the authority of the 'givenness' of God's self-revelation (Chung 2011:62). As a critical realist, 
Torrance begins with the assumption that God can be known and that God has acted in space-time history, particularly in Jesus Christ (Kelly 2007:75; Torrance 1982:58-60, 97-99; 1990:52-53, 136). Torrance rejects the God-world divide of cosmological dualism, be that the dualism of the ancient Greeks or of Newtonian Deism, as well as the epistemological dualism of Kant, with its bifurcation of the knower and the known (Torrance 1980:15ff.). For Torrance, dualism distorts the revelation and mediation of God in Jesus Christ (Chung 2011:32; Luoma 2002:87). Thus, one of the main aims of Torrance's scientific theology is to bring to light and correct the ramifications of dualism embedded in Western theology (Morrison 1997:28-30).

\section{Kataphysical inquiry}

Torrance's doctrine of the mediation of Jesus Christ is strongly influenced by the methodology of the natural sciences. The 'fundamental axiom' (Colyer 2001a:322), 'quintessence' (Myers 2008:2-3), and 'cardinal principle' (Chung 2011:63) of Torrance's scientific theological method is that knowledge in any field of inquiry must be developed according to the nature of the reality under study (Torrance 1971:92, 1981:27-29, 1992:25; Palma 1984:7; McGrath 1999:209, 234-235). Torrance describes this general methodological principle as 'kataphysic inquiry,' derived from the Greek kata physin [according to nature] (Torrance 1988a:51, 1994:45-46).

For Torrance, to know God through the incarnate Son, who is of 'one nature with the Father' (homoousios to patri), is to know God in strict accordance with God's nature and, hence, in a theologically scientific way (cf. Torrance 1969:110-113; 1988a:3, 51-52). Because God has given himself to be known in Jesus Christ, scientific theology will operate on a Christological basis. Rather than go 'behind the back' of Jesus to develop knowledge of God, argues Torrance, Christology teaches us to know God in strict accordance with the way He has made himself known in historical space-time (Torrance 1990:71).

For Torrance, scientific theology is never the product of $a$ priori thought; rather, it is developed a posteriori in encounter with the incarnation of Jesus Christ, who is the definitive reference for true knowledge of God (Torrance 1969:33; Ho 2008:23; Myers 2008:4). In regard to theological knowledge, argues Torrance (1969:131-132, 1994:47, cf. 1985:26-27), our human way of knowing undergoes a radical change, that is, an 'epistemological inversion', wherein God is 'Lord of our knowing'. Unlike ordinary objects of scientific investigation, God cannot be controlled and manipulated in the process of scientific inquiry. We can only know God in accordance with his gracious self-revelation. Therefore, for Torrance (1969:33; 1984:194; cf. Grenz 2004:205), faith is the appropriate epistemic stance towards the object of scientific theological inquiry. Because God is the absolute subject who freely chooses to give himself to be known and determines the method by which He will be known, faith is an essential part of the epistemological inversion required in Torrance's kataphysical method (cf. Torrance 1969:132).

\section{Onto-relationality}

A corollary to Torrance's fundamental principle of 'kataphysical' inquiry (cf. McGrath 1999:235) is his basic conviction concerning the 'dynamic interrelationality' of reality, a theological principle inspired by his reading of the nineteenth-century natural scientists and devout Christians, Michael Faraday (1791-1867) and James Clerk Maxwell (1831-1879), as well as the early twentieth-century scientist, Albert Einstein (1879-1955). Clerk Maxwell and Faraday discovered that the elemental aspects of reality do not exist as discrete particles in isolation from one another, as in the atomism of Newtonian cosmology, but rather as 'particlesin-relation' to one another by virtue of the electromagnetic 'force fields' in which they are embedded and through which they are connected or interrelated. As a way of describing particles as inseparable from their interrelations, Maxwell developed the concept of the 'continuous dynamic field' as an independent reality, a discovery that Einstein called the most important change to have ever taken place in the logical structure of natural science (Torrance 1984:215ff., 1988b:161, 2002:12-34; Neidhardt 1989:87ff.).

Because the fundamental aspects of reality exist within nexuses of 'being-constituting' relations, or 'onto-relations' (Torrance 1992:47-50), the goal of Torrance's scientific theology is to investigate and to coherently articulate the essential interrelations embodied in our knowledge of God through Jesus Christ in the Holy Spirit. For Torrance, a scientific theology will view the mediation of Jesus Christ within the nexuses of interrelations that disclose his identity and mission. Torrance finds this kind of approach in the early Church, where Jesus' followers sought to understand his significance within the 'dynamic field' of God's covenant interaction with Israel and also in light of his relationship with God. Within this complex of interrelations, notes Torrance:

... the startling events in the life, death and resurrection of Jesus fell into place within a divinely ordered pattern of grace and truth, and the bewildering enigma of Jesus himself became disclosed: he was incarnate Son of God and Saviour of the world. (Torrance 1992:1-5; cf. Colyer 2001a:55-57, 345)

\section{Elemental forms}

In developing knowledge in accordance with the nature of its object of inquiry, notes Torrance, scientific activity engages in a movement of thought from the many to the one, from the complex to the simple, in order to reduce the multiplicity of its knowledge to a number of basic concepts. These 'elemental forms' have the effect of illuminating a great variety of otherwise incomprehensible facts and, thereby, represent a vast simplification of a broad range of knowledge. This methodological principle, known as 'Ockham's razor', was reiterated by Einstein, who asserted that the aim of science was to comprehend as completely as possible the reality under study whilst using a minimum of primary concepts and relations to describe it. Einstein referred to this process as 'logical simplicity' or 'logical economy'. Torrance applies this process to theological science in order to reduce the 
entire body of theological knowledge to a few elemental forms (Torrance 1969:116-119, 1985:152-157).

The Nicene homoousion and the doctrine of the hypostatic union constitute the primary elemental forms of Torrance's doctrine of the mediation of Jesus Christ. These basic theological concepts provide a 'disclosure model' or conceptual 'lens' through which realities reveal themselves in a progressive way that simplifies and clarifies our knowledge of God and enables us to integrate the complexity of Scripture in a way that illumines God's self-revelation in the economy of salvation, whilst strengthening our faith and experience (Torrance 1980:125-126; Colyer 2001b:225).

As Purves (2001:73-74) notes, the remarkable feature of Torrance's theology is not the use of the homoousion and the hypostatic union, for these are 'common theological currency', but, rather, the importance Torrance attaches to these concepts in order to apprehend what God is ontically in himself. These concepts are Torrance's primary 'Christological tools', with the homoousion being of decisive importance as the central organising truth at the level of the economic Trinitarian relations. Purves rightly asserts that Torrance's contribution lies in his identification of the epistemological and soteriological significance of the homoousion and the hypostatic union and that his 'genius' is that he has investigated the implications of a Christologicallymediated knowledge of God to the extent that he has.

In addition to the homoousion and the hypostatic union, two other elemental forms readily arise as corollaries of Torrance's understanding of the doctrine of the hypostatic union. These are his doctrine of 'incarnational redemption', an articulation of the internal, ontological relationship between the incarnation and the atonement, and his doctrine of the 'vicarious humanity' of Jesus Christ, an articulation of the incarnate Son's relation with the Father as man.

The elemental forms of Torrance's thought reflect the unitary character of his scientific theology, that is, his 'theological holism', for each elemental form displays an inherently relational, non-dualist character. By asserting the consubstantial relation between Jesus and God, the homoousion disavows a dualism between the incarnate Son and the Father, such as is found in adoptionist and Arian Christologies. Asserting the union of divine and human natures in the incarnation, the hypostatic union negates a docetic dualism that separates Jesus from humanity. Moreover, by articulating the internal, ontological relation between the incarnation and the atonement, Torrance's doctrine of incarnational redemption disallows a dualism between the person and work of Jesus Christ. Finally, Torrance's doctrine of the 'vicarious humanity' of Jesus Christ depicts the intrinsic, ontological connection between the faith and obedience of the Son of God as man and our own salvation.

\section{The Nicene homoousion}

In Torrance's kataphysical method of inquiry, realities must be investigated within the nexuses of interrelations in which they exist, for these interrelations are constitutive of the nature of the realities in question. Therefore, a theologically scientific examination of the mediation of Jesus Christ requires that He be investigated within the nexus of his consubstantial relation with God.

For Torrance, the Nicene creedal assertion that Jesus Christ is 'of one nature with the Father' (homoousios to patri), is the 'controlling centre' or 'decisive hinge' upon which the entire Christian view of God turns. It is the 'supreme regulative principle' of conciliar theology from Nicaea to Chalcedon, when the classical foundation of Christian theology was laid (Torrance 1985:156-157). As Molnar (2009:101; cf. Chung 2011:15) rightly notes, even the most cursory examination of Torrance's theology will disclose the centrality of the Nicene homoousion for Torrance's doctrine of the mediation of Jesus Christ.

\section{Epistemological significance of the homoousion}

As the 'epitomized expression' of Jesus' consubstantial relation with the Father, Torrance regards the Nicene homoousion as the 'ontological and epistemological linchpin' of Christian theology: 'With it, everything hangs together; without it, everything ultimately falls apart' (Torrance 1980:160-161; cf. 1996:95). For Torrance, the incarnation of Jesus Christ, who is 'of one nature with the Father,' constitutes the 'epistemological centre' of our knowledge of God, with a centre in our world of space and time and a centre in God himself. In the incarnation, an 'epistemic bridge' is established in Christ between God and humanity that is grounded in both the being of God and our own creaturely being (Torrance 1980:165).

Torrance often notes the Patristic assertion that 'only God can reveal God'; that is, no knowledge of God is possible apart from God's revelation of himself (Torrance 1983:8ff.; 1988a:54; 1994:54; 1996:77). For Torrance, the Nicene homoousion concisely expresses the fact that what God is in our midst in Jesus Christ, God really is in himself (Torrance 1988a:130-131, 1996:129). As Torrance (1992:23) argues, Jesus Christ is the Revelation of God. Therefore, a Christian doctrine of God must be developed from the 'unique, definitive, and final self-revelation of God' in Jesus Christ, in whom God defines and identifies himself for us as He really is, 'inherently and eternally in himself' (Torrance 1996:1). For Torrance, God's gracious condescension to make himself known to us in historical space-time in the incarnation of Jesus Christ is the epistemological equivalent of sola gratia (Torrance 1970:126, 1990:143-145; cf. Seng 1992:362-365).

Since we cannot know God 'behind his objectivity' (Ho 2008:23), but only in Christ, knowledge of God arises in accordance with the divine nature (kata physin) revealed in the incarnation. Therefore, in Torrance's kataphysical method, 'knowing' follows 'being', that is, epistemology follows ontology (Kelly 2007:76; cf. Hardy 1997:257; Morrison 1997:149; Ho 2008:23-24; Myers 2008:4).

\section{Evangelical significance of the homoousion}

The evangelical significance of the homoousion becomes clear as it bears upon the saving acts of Jesus Christ. As Torrance 
argues, the incarnate Son's redemptive activity arises from his consubstantial relation with the Father, for his saving acts are nothing less than the acts of God 'for us and for our salvation'. In contrast, if Jesus Christ is detached from God, as in Arian Christology, so that his word and act do not arise from the being and reality of God, then they amount to nothing more than the words and activity of a moral teacher of note and leave the Gospel empty of any divine reality or validity (Torrance 1988a:141-142, 1992:57-58, 1994:53-54, 1996:21).

There are important pastoral considerations in connection to the evangelical significance of the homoousion. Torrance describes his experience as a chaplain on the battlefield when he embraced a dying soldier who asked, 'Is God really like Jesus?' Any disjunction between the being of Jesus and the being of God, notes Torrance, disrupts the message of grace contained in the Gospel and introduces anxiety into the hearts of many Christians, who fear there may be an inscrutable, arbitrary deity hidden 'behind the back of Jesus', before whom we quake and shiver with dread as our guilty consciences 'paint harsh angry streaks upon his face'. However, great comfort and assurance arise 'when the face of Jesus is identical with the face of God ... when the perfect love of God embodied in him casts out all fear' (Torrance 1992:59-60, Torrance, Torrance \& Torrance 1999:16). As Torrance frequently notes, there is no dark, inscrutable deity hidden behind the cross of Christ, for whoever has seen Jesus has seen the Father (Jn 14:9). There is no other God than the God who has shown himself in the compassionate face of Jesus Christ, the very same God who has loved us to the uttermost in the incarnate Son and the gift of the Spirit (Torrance 1986a:303-304, 1988a:8, 1990:176).

Torrance also notes the evangelical significance of the homoousion in terms of judgement. The believer may find assurance in Torrance's connection between Jesus the compassionate Saviour and Jesus the Judge into whose hands all judgement has been given (Jn 5:22), for the hands of Jesus and the hands of God are the same (Torrance et al. 1999:17). There is great comfort in knowing that our final destiny lies in the hands of the one who cried from the cross on behalf of his tormentors, 'Father, forgive them, for they know not what they do' (Lk 23:34), for, in Torrance's trenchant, compelling words, 'the voice of divine forgiveness and the voice of divine judgement are one and the same' (Torrance et al. 1999:15; cf. Torrance 1988a:8, 142-143).

The evangelical significance of the homoousion is the good news that the loving, saving acts of Jesus are, in fact, the acts of God for us and for our salvation. As Torrance argues, 'God does not and will not act toward any one in life or death in any other way than he has done, does do, and will do in Jesus' (Torrance et al. 1999:16), for, in loving us in the gift of his dear Son, who is 'of one nature with the Father', God loves us with the very love which he is (Torrance 1996:5).

\section{Hypostatic union}

Not only must Jesus Christ be viewed within the nexus of his interrelations with God. He must also be viewed within the nexus of his interrelations with humanity. Thus, in addition to the Nicene homoousion, the hypostatic union of divine and human natures in the one person of Jesus Christ is a primary elemental form in Torrance's doctrine of the mediation of Christ.

\section{Epistemological significance of the hypostatic union}

In regard to epistemology, the hypostatic union of divine and human natures in the one person of Jesus Christ has vital implications for the knowledge of God. At Caesarea Philippi, Jesus asked Peter, 'Who do you say I am?' (Mt 16:15). In the Torrance theological tradition, the 'Who?' question takes priority over the 'How?' question (Purves 2007:24-25; Cass 2008:172). Before we can fully consider the work of atoning reconciliation, we must first understand who Jesus Christ is. How Jesus Christ provides atoning reconciliation is a direct function of who he is as the incarnate Saviour, who is at once both fully God and fully human.

Whilst Torrance puts great emphasis on the divinity of Christ by constituting the Nicene homoousion as the epistemological centre of his doctrine of mediation, he does not diminish the epistemological significance of the humanity of Christ. In Jesus Christ, argues Torrance (2008:185-186, 192), God speaks in a human voice, in human language; thus, it is possible for us to know him, not as a result of any innate human capacity to know the divine, but solely on the ground that God graciously chooses to meet us within the limitations of our creaturely existence. For Torrance, the very 'creatureliness' of Jesus Christ constitutes the act of divine revelation in a means accessible to humankind.

For the human voice of Jesus to be divine revelation, however, it must be 'grounded on the reality of God's presence in it, the reality of God's act of self-communication in and through it'. As Torrance (2008) argues:

Thus the full reality of Christ's deity is essential to revelation, and faith, for the reality of revelation is grounded in the reality of the action and presence of God in Christ, on the identity of his revelation with God's self-revelation. (pp. 188-189)

Nevertheless, not even in Jesus can we bridge the gap between God and humanity unless his human speech and acts are predicates of the one divine person. Without the hypostatic union, we would not hear God in Jesus' creaturely speech; yet, because he is both divine and human, in the creaturely speech of Jesus Christ, we hear the language of God. As Torrance (2008:192-193) argues, 'It is only in that union in which God's language condescends to take on creaturely form, and human language is joined to God's language, that there is real revelation.'

\section{Evangelical significance of the hypostatic union}

In addition to its epistemological significance, the hypostatic union of divine and human natures in the one person of Jesus Christ is of vital soteriological significance. In regard to human salvation, it is not enough that Jesus Christ is 'of one nature with the Father'. To be mediator between God and humanity, Jesus Christ must also be homoousios with 
humanity; that is, Jesus Christ must be fully human as well as fully divine (Torrance 1988a:3-4, 146). As Torrance (1988a:8) argues, if Jesus Christ is not fully human, then the bridge that God has cast across the gulf between himself and humanity has not reached us. Hence, the creed stresses the 'stark reality and actuality' of the humanity of Jesus Christ, whilst emphasising the soteriological purpose of the incarnation: it was 'for us and for our salvation' that God became human.

In contrast, if the humanity of Jesus Christ is the guarantee of God's historical action amongst us as a human being, the deity of Christ means his mediation of reconciliation is imbued with 'the full reality of God himself'. 'What Jesus does in forgiveness is not just the work of man', argues Torrance, 'but the work of God, and is therefore of final and ultimate validity ... [for] it is God himself who acts in Jesus Christ' (Torrance 2008:187). As Torrance notes: '[A]s the obverse of the fact that Christ's real humanity means that God has actually come to us and dwells among us, Christ's deity means that God himself has come to save us.' To be sure, the Gospel rests upon the fact that it is God who became incarnate in Jesus Christ and that it is God who in Christ has reconciled the world to himself (2 Cor 5:19; Torrance 2008:188-190).

Moreover, not only is the humanity and deity of Jesus Christ essential for the mediation of reconciliation. The hypostatic union of divine and human natures in the one person of Jesus Christ is also essential for our salvation. In alignment with the communicatio idiomatum of Alexandrian Christology, Torrance argues that the doctrine of the hypostatic union is the assertion that, in the mystery of Christ, 'divine and human natures and acts are truly and completely united in one person or hypostasis', so that the divine acts in the human nature of Jesus and the human acts in the divine nature of the eternal Word 'are both acts of one and the same person' (Torrance 2008:190-191). Torrance is careful to assert that there are not two acts in the life and death of Jesus Christ but only one act by the God-man, a single action which is at once 'Godward' and 'humanward'. If atonement is to be real, it must take place from humanity's side if we are to be reconciled to God. Yet, it must also take place from the side of God, that is, as atonement by God for humankind, if it is to be effectual. Echoing Athanasius, Torrance argues that only the Word through whom humanity was made, by himself becoming human, can act in humanity's place in such a way as to recover and restore that which man lost (cf. Kruger 2003:15ff.). Hence, atonement is the work of the God-man, of God and man in hypostatic union; it is not merely the work of God in man, but an act of God as man (Torrance 2008:195).

As Torrance (2008:190) notes, the mystery of our salvation lies in the indivisible, inseparable, unconfused and unchangeable personal union of divine and human natures in Jesus Christ. In order to reveal God to us, Jesus must be God speaking within the limitations and constraints of human thought and speech. In order to reconcile humanity to God, Jesus must be human, so that his acts reach us; at the same time, he must be divine, for only God can save. Yet, for the mediation of revelation and reconciliation to be valid, all Jesus' acts 'for us and for our salvation' must issue from one person, so that every act is both human and divine. As Torrance argues, 'Only he can be mediator who is himself the union of God and man, only he can be pontifex (bridgemaker) who is himself the pons (bridge).'

\section{Incarnational redemption}

As a direct correlate of the doctrine of the hypostatic union, Torrance emphasises the twofold movement of mediation (Purves 2005:2-3), wherein Jesus Christ mediates the things of God to humanity and the things of humanity to God in a unitary movement of atoning reconciliation (Torrance 1986b:479, 1992:73). The elemental form, or basic constitutive concept, that reflects the 'Godward-humanward' movement of the mediation of Jesus Christ is Torrance's doctrine of 'incarnational redemption'.

For Torrance (2008), the atonement presupposes the doctrine of the hypostatic union of divine and human natures in the one person of Jesus Christ:

... for the whole work of reconciliation depends upon the fact that one person acts both from the side of God, and from the side of man, both in his divine acts and in his human acts, and that these acts are really and truly identical in the person of the mediator. (pp. 183-184)

In his incarnate constitution as God and humanity joined together in the hypostatic union of divine and human natures in one person, argues Torrance (1986b:475-476, 1990:204), Jesus Christ is atoning reconciliation

In Torrance's unitary, non-dualist theology, the incarnation and the atonement are internally connected: incarnation is inherently redemptive and redemption is inherently incarnational (Torrance 1988a:159, cf. 1992:66; Cass 2008:169ff.). As Molnar (2009:137ff.) rightly notes, for Torrance incarnation and reconciliation are one in Jesus Christ.

\section{Assumption of fallen Adamic flesh}

The inherent connection Torrance sees between the incarnation and the atonement depends heavily upon the Patristic view, 'found everywhere in the early Church in the first five centuries' (Torrance 1992:39), that the eternal Son assumed 'fallen Adamic humanity' from the Virgin Mary, that is, 'our perverted, corrupt, degenerate, diseased human nature enslaved to sin and subject to death under the condemnation of God' (Torrance 1988a:161, cf. 1994:58). Torrance's assertion of the assumption of fallen Adamic flesh is based on the soteriological principle given central place in the theology of Athanasius, Cyril and the Cappadocian fathers, and given its most epigrammatic expression in Gregory Nazianzus' trenchant refutation of Apollinarianism: 'the unassumed is the unhealed' (Torrance 1988a:163-165). The early fathers understood that that which is not assumed by Jesus Christ in the incarnation is not saved (Torrance 1992:39). 


\section{Unity of Christ's person and work}

In asserting the assumption of sinful human flesh, Torrance (1986b:476-478, 480; cf. 1990:232-233; 1992:40-41; 1993:237$239 ; 1994: 58-59)$ rejects what he terms the 'Latin heresy', that is, a 'dualist' understanding of the person and work of Christ, wherein the atonement is formulated in terms of external relations, whether exemplary, as in Abelard, or juridical, as in Anselm. According to Torrance, Latin theologians bifurcated the intrinsic, unitary relation between the person and work of Christ by construing the atonement in an 'instrumentalist' way, wherein the incarnation was regarded simply as a means of supplying a sinless human being who could bear our sins on the cross. In contradistinction to the Latin heresy and its 'gospel of external relations,' Torrance follows Patristic theology in arguing that the incarnation and the atonement are 'internally linked' (Torrance 1992:41). In Christ, the incarnation and the atonement are 'one and inseparable', for atoning reconciliation takes place within, not 'external' to, or 'outside', his incarnate constitution as mediator between God and humanity (Torrance 1986b:475476). As Purves (2001:59) rightly notes, this means that the hypostatic union must be understood not only in terms of the incarnation but also in terms of soteriology, that is, in terms of atoning reconciliation between God and humanity, whilst reconciliation must be understood not only in terms of the cross, but also in terms of the incarnation.

Against an external view of atonement, wherein the sinless Saviour offers his body in an instrumental way as payment for sin, Torrance's insists on an 'ontological' view of incarnational redemption, wherein atonement is worked out within the ontological depths of human existence into which the Son of God penetrated in the incarnation. For Torrance, the root of the human dilemma is alienation from God as a result of sin, coupled with human enslavement to a nature determined by its fallen condition. Sin is, thus, far more than a merely moral or forensic problem. It is a problem; it is the state in which we exist, a state of existential estrangement from our Maker. As an ontological problem, sin must be dealt with at the depths of our fallen, diseased humanity (Hart 2008:81; cf. Torrance 1992:70).

For Torrance, therefore, the hypostatic union is not merely a static union of divine and human natures. Rather, it is a 'dynamic atoning union' wherein the actual condition of human estrangement and conflict is brought into 'perfect sanctifying union' with God (Torrance 1992:65-66). In the hypostatic union of divinity and fallen Adamic flesh in Jesus Christ, God penetrates to the ontological depths of our sinful humanity, healing our corrupt flesh, making whole our brokenness and removing our sin and guilt by sanctifying it in atoning union in the incarnation. Atonement, therefore, is not to be understood in terms of 'external relations' between human sins and Jesus Christ, wherein the incarnate Saviour assumes only our actual sins but in terms of his 'incarnational penetration' into the ontological depths of human existence in such a way as:
... to get at the very roots of our original sin and guilt and through his expiatory and propitiatory activity, not only to do away with our sin and guilt, but to sanctify us and creatively to set our life on an altogether new basis in union with himself. (Torrance 1986a:306; 1990:178-179)

Atoning reconciliation, therefore, must be understood as accomplished within the incarnate constitution of the mediator Jesus Christ rather than as an external transaction between God and sinful humanity. As Torrance cogently argues, Jesus Christ does not mediate a revelation or reconciliation other than what he is in himself as the incarnation of God and sinful humanity in reconciling union. The incarnate Saviour embodies what he mediates, 'for what he mediates and what he is are one and the same'. As the 'content' and 'reality' of reconciliation, Jesus Christ 'embodies the Gospel of reconciliation between God and man and man and God in his own Person'. 'he is the Propitiation for our sins; he is our Redemption; he is our Justification' (Torrance 1986b:475-476; cf. 1988a:155, 1992:63). As Pratz (1998:6) simply but accurately states, 'What he is is what he does'.

For Torrance (1990:204), Jesus Christ is 'the centre of it all', mediating reconciliation in such a way that, in him, we are with God. 'In the deepest sense', notes Torrance 'Jesus Christ is himself the atonement'.

\section{Universal reconciliation, not universalism}

An important aspect of Torrance's unitary view of the incarnation and the atonement is his doctrine of universal reconciliation, wherein he brings together the doctrines of creation, incarnation, and atonement. Not only is Jesus Christ the Lamb of God who takes away the sin of the world (Jn 1:29), he is also the incarnate Word through whom all things were made (Jn 1:3; Col 1:16; Heb 1:2). Therefore, for Torrance, the doctrines of redemption and creation cannot be separated, but must be allowed to interpenetrate one another. As the 'Head of creation', argues Torrance, the incarnate Word stood in complete 'somatic solidarity' with humanity, offering himself in place of, and on behalf of, all creation, so that his redemptive work is universal in range (Torrance 1986b:474, 1988a:157).

For Torrance, anything short of universal atonement implies a circumscribed incarnation and a limitation in the love of God (Habets 2008:345). To hold that some are not included in the incarnational redemption of Jesus Christ is to undermine his reality as the one by whom all things were created and in whom all things consist ( $\mathrm{Col} 1: 16-17)$. Because he is the embodiment of the creative source and ground of all things (cf. Ac 17:28), every human being is 'ontologically bound' to the Creator Word. 'Whether they believe it or not', argues Torrance, every human being is 'creatively grounded' and 'unceasingly sustained' in Jesus Christ, the incarnate Creator (Torrance 1993:244-245, cf. 1988a:182-183).

Whilst Torrance opposes any limitation in the range of atonement in favour of a doctrine of universal reconciliation, he is not a universalist, for he regards both the doctrines of 'limited atonement' and 'universalism' as 'twin errors' 
arising from the construal of a logico-causal relation between grace and human salvation (Torrance 1981:136). Against universalism, Torrance formulates a doctrine of reprobation, regarding the reprobate as those who, subject to the irrational and accidental nature of sin, inexplicably reject God's love as revealed in his gracious universal pardon (Torrance 1949:316-317, 1981:136, 1993:248, 2009:157-158; Torrance et al. 1999:31).

\section{The vicarious humanity of Jesus Christ}

Representing the 'humanward-Godward' movement of mediation, another of the elemental forms of Torrance's thought, and a second corollary of his doctrine of the hypostatic union, is his doctrine of the 'vicarious humanity' of Jesus Christ.

The incarnate Word, Jesus Christ, embodies in himself the personal address of God's Word to humanity and the perfect human response to God's Word. Jesus Christ is both the revealing God and the perfectly responding man, fulfilling the covenant from both sides, both as the covenant-making God and the covenant-keeping man (Torrance 1992:77-78). For Torrance (1971:145), the Gospel is not to be understood as the Word of God coming to us and inviting our response only. Rather, the Gospel includes the divinely-provided response rendered for all in the vicarious humanity of Jesus Christ.

The perfect atoning response that Jesus offered to the Father includes the entirety of his life, from birth through death, resurrection, and ascension, or what Calvin (2008:1059) called 'the whole course of his obedience'. In both his active and passive obedience (Torrance 1960:229-231), the incarnate Word yielded the perfect human response to the divine revelation He embodied, thereby sanctifying every stage of human life (Torrance 1988a:167-168).

In regard to the vicarious obedience Jesus rendered for all, Torrance (1992:80-81, cf. 1988a:168) brings together the concepts of 'representation' and 'substitution'. For Torrance, Jesus is no mere leader who represents humanity, nor is he merely a substitute who stands in for us at the cross in an external forensic way. Rather, Jesus Christ acts on our behalf from within the depths of the fallen Adamic humanity he assumed in the incarnation, so that there is an ontological connection between all humanity and his representative and substitutionary acts. 'As man,' argues Torrance, Jesus Christ acts in our place in all aspects of humankind's response to God, so that we may share with him in all his acts of obedience to the Father (Torrance 1971:145, 1976:136, 1986b:479, 1994:30-31).

Torrance (1976:141) identifies Galatians 2:20 as a passage of 'primary importance' in his doctrine of vicarious humanity. As Purves (2005:1-2) rightly notes, this verse functions in a 'hermeneutical manner' by providing a significant point of access for understanding Torrance's doctrine of the vicarious humanity of Jesus Christ. Torrance (1994:31; Torrance et al. 1999:24, 25; cf. Torrance 1957:113) follows the King James Version in translating pistis christou in the subjective genitive (i.e. faithfulness of Christ) (cf. Bird \& Sprinkle 2010:350). As Torrance argues, it is not our faith in Christ that saves us, but we are saved by the faith of Christ, who offers, in our place and on our behalf, the perfect human response of faith (and obedience) that we are unable to offer (Torrance 1957:113-114, 1992:82-84, 1994:31-32; Torrance et al. 1999:25-26).

The 'I, yet not I but Christ' of Galatians 2:20 provides the hermeneutical framework for Torrance's doctrines of faith (1992:81-84, 98), justification and sanctification (Torrance 1960:225ff.), conversion (Torrance 1992:84-86), worship and prayer (Torrance 1976:139ff., 1992:87-89), the sacraments (Torrance 1976:82ff., 106ff., 1992:89-92) and evangelism (1992:92-98). In all these aspects of human response to the Gospel, argues Torrance, Jesus Christ, our High Priest and Mediator, takes up our frail human responses and unites them to his own self-offering to the Father. Hence, our own individual responses are neither undermined nor rendered redundant by the vicarious response of Jesus Christ. Rather, they are undergirded and included in his substitutionary and representative acts in place of and on behalf of all.

\section{Summary}

A basic order or progression of ideas underlies Torrance's doctrine of the mediation of Jesus Christ, beginning with his fundamental methodological axiom that scientific knowledge must be developed according to the nature (kata physin) of the object of study as revealed in the course of investigation. In Torrance's method of kataphysical inquiry, epistemology follows ontology. Thus, a priori knowledge is excluded as scientific theological knowledge is developed a posteriori in absolute fidelity to the nature of the object of inquiry, which is God revealed in Jesus Christ, who 'of one nature with the Father'. Moreover, in Torrance's kataphysical method, our human way of knowing undergoes an 'epistemological inversion' as we, by faith, submit our minds in humble obedience to the gracious self-revelation of the God who is 'Lord of our knowing'.

From Torrance's kataphysical method, two other basic principles readily emerge: 'onto-relationality' and 'theological holism'. Because realities exist, not in isolation, but within nexuses of 'being-constituting' interrelations, a scientific theology will investigate the nature of its object of study within the nexuses of 'onto-relations' in which it exists. For Torrance, a scientific theological inquiry into the mediation of Jesus Christ will investigate him within the nexuses of onto-relations that disclose his identity as Son of God and son of man. That is, the mediation of Jesus Christ will be viewed within the nexuses of his consubstantial relation with the Father and his consubstantial relation with humanity.

Following the principal of logical simplicity, the wide array of Torrance's thought can be reduced to a minimal number of elemental forms that, taken together, provide a conceptual lens through which to view his doctrine of the mediation of Jesus Christ. The unitary, non-dualist character of each 
elemental form displays the 'theological holism' of Torrance's thought. The Nicene homoousion, an articulation of the Son's consubstantial relation with the Father, and the Chalcedonian doctrine of the hypostatic union, describing the Son's consubstantial relation with humanity, constitute the primary elemental forms of Torrance's doctrine of the mediation of Jesus Christ. Corollaries to the doctrine of the hypostatic union are Torrance's doctrine of incarnational redemption, representing the Godward-humanward movement of divine mediation and his doctrine of the vicarious humanity of Jesus Christ, representing the humanward-Godward movement of divine mediation.

In summary, by firmly grounding Torrance's doctrine of the mediation of Jesus Christ in his kataphysical method, wherein the incarnate Saviour is viewed within the nexuses of ontorelations that disclose his identity as Son of God and son of man, the complexity of Torrance's thought can be reduced to a minimal number of elemental forms that capture the holistic, non-dualist character of his scientific theology.

\section{Critique}

The new reader who encounters the scientific theology of T.F. Torrance expecting to find 'proofs' of the existence of God or new empirical evidence for the resurrection will be disappointed. Torrance's use of the word science has a slightly different meaning than its popular use. For Torrance, 'science' is reflected in the German word wissenschaftlich, which, according to Ho (2008:19), 'carries a meaning of truthful undertaking of a rigorous and disciplined inquiry of the object according to its unique nature' (cf. Torrance 1964:149-150; 1969:116-117). Torrance's kataphysical inquiry into the Object of scientific theological study requires that knowledge of God be developed according to the divine nature revealed in Jesus Christ. For Torrance, therefore, the Nicene homoousion is the epistemological linchpin and controlling centre for knowledge of God.

Torrance's insistence that realist knowledge of God arises solely in the context of the consubstantial Father-Son relation interactive in human history, however, is not without its critics. As Purves (2001:72) notes, the singularity of Jesus Christ in regard to knowledge of God is still a hotly contested issue. Since Torrance insists that Jesus Christ is the one in whom knowledge of God is actual, rather than merely speculative or mythological, does this mean, asks Purves, that knowledge of God is confined to an 'epistemological ghetto', wherein there can be no independent appeal to truth claims regarding divine knowledge? Here Purves finds operating a 'kind of scientific theological fideism' that is the result of the nature of God's self-revealing act in Jesus Christ. We can only know God, because we have faith in Jesus Christ and, thereby, participate in his knowledge of the Father.

Similarly, as Ho (2008:24-28) observes, Torrance appeals to the necessity of faith in order for us to know that the 'centre of our knowing' is in God, rather than in us, and that God's revelation is reliable and faithful (cf. Torrance 1969:132-264). Whilst paramount in Torrance's thought, however, the belief in the reliability and faithfulness of God cannot be scientifically (i.e. empirically) validated. Moreover, Ho argues, whilst Torrance rightly insists that we abandon all presuppositions in order to develop a posteriori knowledge of God according to the divine nature revealed in Jesus Christ, he introduces his own unprovable presupposition by asserting that ultimate reality cannot be validated outside itself. By presupposing the existence of an ultimate reality that cannot be scientifically proven and, even more, argues Ho, by presupposing that this reality is the Christian God of the Holy Bible, Torrance introduces a presupposition that overrides all other presuppositions, whilst providing little apologetic support for his position. By introducing personal faith into his scientific theology, whilst detaching it from scientific validation, Torrance introduces an inconsistency into his scientific theology that some may find problematic.

Another problematic aspect of Torrance's doctrine of the mediation of Jesus Christ is his assertion that the eternal Word assumed fallen, sinful Adamic flesh in the incarnation in order to heal and sanctify it in ontological, reconciling union. This view is an essential aspect of the inherent, unitary relation Torrance sees between the incarnation and the atonement. Whilst Torrance maintains that this view was prominent in the early church, particularly amongst the Greek fathers, there are divergent historical assessments regarding the prevalence of this view in the early church, although the preponderance of evidence appears to favour Torrance's position (Kapic 2001:156-160). To be sure, Torrance's array of Patristic support for the 'fallenness' position is convincing (Torrance 1988a:161-165). In addition, Torrance's view is supported by a number of modern theologians, including Protestant Karl Barth and Roman Catholics Hans Urs von Balthasar and Thomas Weinandy (Kapic 2001:155, 159; McFarland 2008:404-405). Moreover, Molnar (2009:150) notes that this view is commonly espoused in Eastern theology. Despite its modern proponents, however, the assertion of the Son's assumption of fallen Adamic flesh remains the subject of debate (Kapic 2001:154ff.; Crisp 2004:270ff.; Allen 2007:382ff.; McFarland 2008:399ff.). Cass (2008:181-182) even argues that this view is rejected by the 'vast majority' of Roman Catholics, liberal Protestants, Evangelicals, and even many Reformed theologians. If Torrance's position is incorrect, then his assertion that the incarnation is a healing, reconciling, ontological union that penetrates to the root of original sin is called into question and his assertion of the inherent relation between the incarnation and the atonement is dramatically weakened. Because of the importance of this subject in Torrance's doctrine of mediation, as well as the continuing debate in its regard, Torrance's assertion of the 'fallenness' position warrants further research.

Another subject of controversy is Torrance's translation of Galatians 2:20, where he translates pistis christou in the subjective genitive (faithfulness of Christ) to support his assertion that it is not our faith in Christ that saves us; rather, we are saved by the faith of Christ. Whilst this passage is an important hermeneutical support for Torrance's doctrine of the vicarious humanity of Jesus Christ, the majority opinion favours the objective genitive (faith in Christ) (Matera 2007:94).

Despite the difficulties that will inevitably arise in an oeuvre as vast as that of Torrance, his scientific (i.e. wissenschaftlich) 
method of kataphysical inquiry is of immense benefit to the church's proclamation of Jesus Christ as the incarnate Saviour of the world. Torrance's method of kataphysical inquiry is the sine qua non of his scientific theology and the foundation of his entire theological enterprise. If one accepts, by faith, that the incarnate Son is 'of one nature with the Father', then Torrance's kataphysical method rightly places Jesus Christ squarely in the centre of the entire theological enterprise and introduces a Christological control to the traditional loci of systematic theology. Torrance's kataphysical method of inquiry is truly 'theo-logical', for it allows epistemology to properly arise from a centre in God rather than, for example, from the projection of human consciousness onto the heavens, whereby theology is reduced to anthropology. As Torrance repeatedly asserts, we must not go 'behind the back of Jesus' to develop knowledge of God. By constituting the Nicene homoousion and the Chalcedonian doctrine of the hypostatic union as the primary elemental forms of his doctrine of the mediation of Jesus Christ, Torrance develops a truly Christian scientific theology (cf. Kruger 1989:8-9).

\section{Acknowledgements \\ Competing interests}

The author declares that he has no financial or personal relationship(s) which may have inappropriately influenced him in writing this article.

\section{References}

Allen, R.M., 2007, Calvin's Christ: A dogmatic matrix for discussion of Christ's human nature, International Journal of Systematic Theology 9(4), 382-397.

Bird, M. \& Sprinkle, P. (eds.), 2010, The faith of Jesus Christ: Exegetical, Biblical, and theological studies, p. 350, Hendrickson, Peabody, MA.

Calvin, J., 2008, Institutes of the Christian religion, trans. H. Beveridge, p. 1059, Hendrickson, Peabody, MA.

Cass, P., 2008, Christ condemned sin in the flesh: Thomas F. Torrance's doctrine of soteriology and its ecumenical significance, PhD thesis, Princeton Theological Seminary, Princeton University.

Chung, T. 2011, Thomas Torrance's mediations and revelation, Ashgate, Farnham, Surrey.

Colyer, E.M., 2001a, How to read T.F. Torrance: Understanding his trinitarian \& scientific theology, InterVarsity Press, Downers Grove, IL.

Colyer, E.M., 2001b, 'A scientific theological method', in E. Colyer (ed.), The promise of trinitarian theology: Theologians in dialogue with T.F. Torrance, pp. 205-237, of trinitarian theology: Theologians in dialogue
Rowman \& Littlefield Publishers, Lanham, MD.

Crisp, O., 2004, 'Did Christ have a fallen nature?', International Journal of Systematic Theology 6(3), 270-288.

Grenz, S.J., 2004, Rediscovering the triune God: The trinity in contemporary theology, Augsburg Fortress, Minneapolis, MN.

Habets, M., 2008, 'The doctrine of election in evangelical Calvinism: T.F. Torrance as a case study', Irish Theological Quarterly 73(3-4), 334-354.

Hardy, D.W., 1997, The integration of faith with scientific thought: Thomas F. Torrance, in D. Ford (ed.), The modern theologians: An introduction to Christian theology in the twentieth century, pp. 257-261, Blackwell Publishing, Malden, MA.

Hart, T., 2008, 'Atonement, the incarnation, and deification: Transformation and convergence in the soteriology of T.F. Torrance', Princeton Theological Review 39(2), 79-90.

Ho, M.K., 2008, A critical study on T.F. Torrance's theology of incarnation, Peter Lang, Bern, Berlin, Bruxelles, Frankfurt am Main, New York, Oxford.

Kapic, K.M., 2001, 'The Son's assumption of a human nature: A call for clarity', International Journal of Systematic Theology 3(2), 154-166.

Kelly, D.F., 2007, 'The realist epistemology of Thomas F. Torrance', in G. Dawson (ed.), An introduction to Torrance theology: Discovering the incarnate Saviour, pp. 75An introduction to Torran
$102, \mathrm{~T} \& \mathrm{~T}$ Clark, London.

Kruger, C.B., 1989, 'Participation in the self-knowledge of God: The nature and means of our knowledge of God in the theology of T.F. Torrance', PhD thesis, King's College, University of Aberdeen.

Kruger, C.B., 2003, Jesus and the undoing of Adam, Perichoresis Press, Jackson, MS.

Luoma, T., 2002, Incarnation and physics: Natural science in the theology of Thomas F. Torrance, Oxford University Press, New York, NY.
Matera, F.J., 2007, Galatians, Liturgical Press, Collegeville, MN.

McFarland, I.A., 2008, 'Fallen or unfallen? Christ's human nature and the ontology of human sinfulness', International Journal of Systematic Theology 10(4), 399-415.

McGrath, A.E., 1999, T.F. Torrance: An intellectual biography', T \& T Clark, Edinburgh.

Molnar, P.D., 2009, Thomas F. Torrance: Theologian of the trinity, Ashgate Publishing, Farnham, Surrey.

Morrison, J.D., 1997, Knowledge of the self-revealing God in the thought of Thomas Forsyth Torrance, Peter Lang, New York, NY.

Myers, B., 2008, 'The stratification of knowledge in the thought of T.F. Torrance', Scottish Journal of Theology 61, 1-15.

Neidhardt, W.J., 1989, 'Thomas F. Torrance's integration of Judeo-Christian theology and natural science: Some key themes', Perspectives on Science and Christian Faith 41(2), 87-98.

Palma, R.J., 1984, 'Thomas F. Torrance's reformed theology', Reformed Review 38(1), 2-46.

Pratz, G., 1998, The relationship between incarnation and atonement in the theology of Thomas F. Torrance, Journal for Christian Theological Research 3(2), viewed 12 May 2012, from http://www2.luthersem.edu/ctrf/JCTR/Vol03/Pratz.htm

Purves, A.P., 2001, 'The Christology of Thomas F. Torrance', in E. Colyer (ed.), The promise of trinitarian theology: Theologians in dialogue with T.F. Torrance, pp. 51-80, Rowman \& Littlefield Publishers, Lanham, MD.

Purves, A.P., 2005, '"I yet not I but Christ": Galatians 2:20 and the Christian life in the theology of T.F. Torrance', paper presented at the Annual Meeting of the T.F. Torrance Theological Fellowship, Philadelphia, Pennsylvania, 17 November, viewed 12 May 2012, from http://www.tftorrance.org/meetings/purveslecture11-05.pdf

Purves, A.P., 2007, 'Who is the incarnate Saviour of the world?', in G. Dawson (ed.), An introduction to Torrance theology: Discovering the incarnate Saviour, pp. 23-32, T \& T Clark, London.

Seng, K.P., 1992, 'The epistemological significance of homoousion in the theology of Thomas F. Torrance', Scottish Journal of Theology 45, 341-366.

Torrance, T.F., 1949, 'Universalism or election?', Scottish Journal of Theology 2, 310-318.

Torrance, T.F., 1957, 'One aspect of the Biblical conception of faith', The Expository Times 68, 111-114.

Torrance, T.F., 1960, Justification: Its radical nature and place in reformed doctrine and life, Scottish Journal of Theology 13, 225-246.

Torrance, T.F., 1964, 'Science, theology, unity', Theology Today 21(2), 149-154.

Torrance, T.F., 1969, Theological science, Oxford University Press, Oxford.

Torrance, T.F., 1970, 'The problem of natural theology in the thought of Karl Barth', Religious Studies 6, 121-135.

Torrance, T.F., 1971, God and rationality, Oxford University Press, London.

Torrance, T.F., 1976, Theology in reconciliation: Essays toward evangelical and catholic unity in East and West, Eerdmans, Grand Rapids, MI.

Torrance, T.F., 1980, The ground and grammar of theology: Consonance between theology and science, T \& T Clark, Edinburgh.

Torrance, T.F., 1981, Christian theology and scientific culture, Oxford University Press, Oxford.

Torrance, T.F., 1982, Reality and evangelical theology: The realism of Christian revelation, Westminster John Knox Press, Westminster, PA.

Torrance, T.F., 1983, 'The deposit of faith', Scottish Journal of Theology 36, 1-28.

Torrance, T.F., 1984, Transformation \& convergence in the frame of knowledge: Explorations in the interrelations of scientific and theological enterprise, Eerdmans, Grand Rapids, MI.

Torrance, T.F., 1985, Reality and scientific theology, Wipf \& Stock Publishers, Eugene, OR. Torrance, T.F., 1986a, 'The legacy of Karl Barth', Scottish Journal of Theology 39, 289-308.

Torrance, T.F., 1986b, 'Karl Barth and the Latin heresy', Scottish Journal of Theology 39, 461-482.

Torrance, T.F., 1988a, The trinitarian faith: The evangelical theology of the ancient catholic church, T \& T Clark, London.

Torrance, T.F., 1988b, 'Realism and openness in scientific inquiry', Zygon 23(2), 159-169.

Torrance, T.F., 1990, Karl Barth: Biblical and evangelical theologian, T \& T Clark, Edinburgh.

Torrance, T.F., 1992, The mediation of Christ, rev. edn., Helmers \& Howard, Colorado Springs, CO.

Torrance, T.F., 1993, 'The atonement, the singularity of Christ and the finality of the cross: The atonement and the moral order', in N. Cameron (ed.), Universalism and the doctrine of hell, pp. 225-256, Baker House, Grand Rapids, MI.

Torrance, T.F., 1994, Preaching Christ today: The gospel and scientific thinking, Eerdmans, Grand Rapids, MI.

Torrance, T.F., 1996, The Christian doctrine of God, one being three persons, T \& T Clark, London.

Torrance, T.F., 2002, Theological and natural science, Wipf \& Stock, Eugene, OR.

Torrance, T.F., 2008, Incarnation: The person and life of Christ, papers collected and edited by R.T. Walker, Inter Varsity Press, Downers Grove, IL.

Torrance, T.F., 2009, Atonement: The person and work of Christ, papers collected and edited by R.T. Walker, Varsity Press, Downers Grove, IL.

Torrance, T.F., Torrance, J.B. \& Torrance, D.V., 1999, A passion for Christ: The vision that ignites ministry, papers collected and edited by G. Dawson \& J. Stein, Handel Press, Edinburgh. 